Article

\title{
Oxidation of Methionine 77 in Calmodulin Alters Mouse Growth and Behavior
}

\author{
Méry Marimoutou ${ }^{1}$, Danielle A. Springer ${ }^{2}$, Chengyu Liu ${ }^{3}$, Geumsoo Kim ${ }^{1}$ and \\ Rodney L. Levine ${ }^{1, *(1)}$ \\ 1 Laboratory of Biochemistry, National Heart, Lung, and Blood Institute, Bethesda, MD 20892-8012, USA; \\ mery.marimoutou@nih.gov (M.M.); kimg@nhlbi.nih.gov (G.K.) \\ 2 Murine Phenotyping Core, National Heart, Lung, and Blood Institute, Bethesda, MD 20892-5570, USA; \\ ds628k@nih.gov \\ 3 Transgenic Core, National Heart, Lung, and Blood Institute, Bethesda, MD 20892-8403, USA; \\ liuch@nhlbi.nih.gov \\ * Correspondence: rlevine@nih.gov; Tel.: +1-301-496-2310
}

Received: 4 September 2018; Accepted: 9 October 2018; Published: 13 October 2018

\begin{abstract}
Methionine 77 in calmodulin can be stereospecifically oxidized to methionine sulfoxide by mammalian methionine sulfoxide reductase $\mathrm{A}$. Whether this has in vivo significance is unknown. We therefore created a mutant mouse in which wild type calmodulin- 1 was replaced by a calmodulin containing a mimic of methionine sulfoxide at residue 77. Total calmodulin levels were unchanged in the homozygous M77Q mutant, which is viable and fertile. No differences were observed on learning tests, including the Morris water maze and associative learning. Cardiac stress test results were also the same for mutant and wild type mice. However, young male and female mice were $20 \%$ smaller than wild type mice, although food intake was normal for their weight. Young M77Q mice were notably more active and exploratory than wild type mice. This behavior difference was objectively documented on the treadmill and open field tests. The mutant mice ran $20 \%$ longer on the treadmill than controls and in the open field test, the mutant mice explored more than controls and exhibited reduced anxiety. These phenotypic differences bore a similarity to those observed in mice lacking calcium/calmodulin kinase II $\alpha(\mathrm{CaMKII} \alpha)$. We then showed that MetO77 calmodulin was less effective in activating CaMKII $\alpha$ than wild type calmodulin. Thus, characterization of the phenotype of a mouse expressing a constitutively active mimic of calmodulin led to the identification of the first calmodulin target that can be differentially regulated by the oxidation state of Met77. We conclude that reversible oxidation of methionine 77 in calmodulin by MSRA has the potential to regulate cellular function.
\end{abstract}

Keywords: calmodulin; methionine sulfoxide reductase A; methionine sulfoxide; methionine; reversible covalent modification

\section{Introduction}

Except for its role in protein initiation, methionine had typically been viewed as a generic hydrophobic amino acid but investigations from many laboratories have changed this view [1-8]. Methionine in proteins functions in antioxidant defense, protein structure and redox sensing/regulation. Reversible covalent modification of proteins, such as phosphorylation and dephosphorylation, has long been appreciated to be a key mechanism of cellular regulation. In the same way, cyclic oxidation and reduction of methionine has the potential to function as a regulatory switch. Such a regulatory function has been established for methionine in actin. The flavin-containing NADPH-dependent oxidoreductase MICAL (Microtubule Associated Monooxygenase, Calponin And 
LIM Domain Containing)mediates the stereospecific oxidation of Met44 in F-actin, leading to its depolymerization [6]. The cytosolic methionine sulfoxide reductase B1 (MSRB1) reduces methionine sulfoxide 44 (MetO44) back to Met, restoring its ability to polymerize [4,5]. The reactions are specific for the R-epimer of MetO. Methionine sulfoxide reductase A (MSRA) is stereospecific for the S epimer and it is a bifunctional enzyme, capable of stereospecifically oxidizing Met and reducing MetO residues [9].

Calmodulin is a substrate for MSRA with an intriguing specificity. There are 9 Met residues in calmodulin, each of which can be oxidized by low molecular weight agents such as hydrogen peroxide or hypochlorous acid. However, MSRA oxidizes only Met77 to S-MetO77 and this can be completely reversed when MSRA operates in the reductase direction [10]. There are hundreds of known targets of calmodulin [11] but to date, regulation by methionine oxidation and reduction in vivo by MSRA has only been implicated in the ripening of bananas [12].

The mammalian genome contains 3 genes encoding calmodulin, all yielding the identical protein sequence but differing in their $5^{\prime}$ promotor and $5^{\prime}$ - and $3^{\prime}$-untranslational regions [13]. Thus, expression of the 3 genes varies from tissue to tissue. The mRNA for calmodulin-1 is highly expressed in brain, testis, intestine and muscle. Expression of calmodulin-2 is very high in brain and testis and well expressed in placenta, lung, thymus, muscle and intestine. Expression of calmodulin-3 is high in brain and testis. In this communication, we report the results of two approaches towards our goal of identifying mammalian targets that are regulated by redox modulation of Met77 in calmodulin. In the first approach, we utilized a micro protein array to identify candidate binding partners of calmodulin. In the second approach, we created a mutant mouse in which Met77 was mutated to glutamine on both copies of the calmodulin-1 gene (Calm1) to create a model of constitutive oxidation of calmodulin-1. Glutamine is a structural analogue of MetO (Figure 1), the hydrophobicities of glutamine and MetO are the same and substitution of Met by glutamine has been demonstrated to mimic MetO [12,14-16]. However, glutamine is not a perfect mimic, as glutamines can pack well into an alpha helix while MetO is incompatible [17].<smiles>NC(=O)CC[C@H](N)C(=O)O</smiles><smiles>CS(=O)CC[C@H](N)C(=O)O</smiles>

Methionine Sulfoxide

Figure 1. Glutamine is an analogue of methionine sulfoxide.

\section{Materials and Methods}

\subsection{Recombinant Calmodulins and Assay of Calcium/Calmodulin Dependent Protein Kinase II $\alpha$ (CaMKII $\alpha$ )}

Wild type and M77Q calmodulins were produced recombinantly to serve as probes of the protein array. MetO77 calmodulin was produced by incubation of wild-type calmodulin with myristoylated mouse MSRA as described [10] and was >99\% MetO form after incubation. M77Q calmodulin DNA (pET17b) was obtained using a QuikChange II Site-Directed Mutagenesis Kit (Agilent 200523, Santa Clara, CA, USA). Primers were 5'-ACCATGATGGCCAGAAAGCAGAAGGACACAGACAGTGAG-3' and 5'-CTCACTGTC TGTGTCCTTCTGCTTTCTGGCCATCATGGT-3' with human calmodulin (pET17b) as the DNA template. Proteins were expressed in E. coli BL21(DE3) cells that were grown 
at $37^{\circ}$ in lysogeny broth (LB) medium containing $100 \mathrm{ug} / \mathrm{mL}$ ampicillin. When the optical density at $600 \mathrm{~nm}$ reached $0.5,0.1 \mathrm{mM}$ isopropyl 1-thio-D-galactopyranoside was added to induce protein expression. Three hours later, cells were harvested by centrifugation at $4^{\circ}$ for $25 \mathrm{~min}$ at $4000 \times g$. The pellet weighed $8 \mathrm{~g}$. Pellets were resuspended in $50 \mathrm{mM} \mathrm{Na}_{2} \mathrm{HPO}_{4}, \mathrm{pH} 7.4$, with $1 \times$ Protease Inhibitor Mixture I (Millipore 539134, Burlington, MA, USA), 1 mM phenylmethanesulfonyl chloride, $1 \mathrm{mM}$ Ethylenediaminetetraacetic acid (EDTA) and 1\% Triton X-100 (Sigma T9284, St. Louis, MO, USA) and then disrupted by French press at 20,000 psi with a cell fitted with a 1 inch piston (Thermo Spectronic, Rochester, NY, USA). The homogenates were centrifuged at $4^{\circ}$ for $20 \mathrm{~min}$ at $25,000 \times g$, which was also the case for all following centrifugations. The supernatant was then made $1 \% w / v$ in streptomycin (Sigma S6501-100G) to precipitate nucleic acids. After rocking $15 \mathrm{~min}$ at $4^{\circ}$, the sample was centrifuged. The supernatant was then brought to $65 \%$ saturation ammonium sulfate by addition of solid ammonium sulfate (Sigma A2989-1KG), rocked for $15 \mathrm{~min}$ at $4^{\circ}$ and centrifuged. The pellet was saved and the supernatant was brought to $90 \%$ saturation in ammonium sulfate. The solution was rocked again for $15 \mathrm{~min}$ at $4^{\circ}$ and was then centrifuged. Pellets were redissolved in and an aliquot analyzed by sodium dodecyl sulfate polyacrylamide gel electrophoresis (SDS PAGE) gel and a Coomassie staining. Both wild type calmodulin and M77Q calmodulin were mostly present in $65-90 \%$ ammonium sulfate pellet. These pellets were resuspended in buffer $\mathrm{A}\left(\mathrm{Na}_{2} \mathrm{HPO}_{4} 50 \mathrm{mM}\right.$, diethylenetriaminepentaacetic acid (DTPA) $1 \mathrm{mM}, \mathrm{pH}$ 7.9) while the supernatants were dialyzed 3 times against buffer $\mathrm{A}$.

The redissolved pellets from the $65-90 \%$ ammonium sulfate cuts of calmodulin and M77Q calmodulin were further purified, with the first chromatographic step being anion exchange chromatography (TosoHass DEAE-5PW, $21.5 \mathrm{~mm}$ ID, $15 \mathrm{~cm}$ length, $13 \mu \mathrm{m}$ particle size). Proteins were eluted by a gradient of buffer $\mathrm{B}\left(\mathrm{Na}_{2} \mathrm{HPO}_{4} 50 \mathrm{mM}\right.$, DTPA $\left.1 \mathrm{mM}, 1 \mathrm{M} \mathrm{NaCl}, \mathrm{pH} 7.9\right)$ developed at $2.5 \% / \mathrm{min}$ at a flow of $3 \mathrm{~mL} / \mathrm{min}$. After dialysis against buffer $\mathrm{A}$, solid ammonium sulfate was added to a final concentration of $1 \mathrm{M}$. Fractions were then subjected to hydrophobic interaction chromatography (TosoHass Phenyl-5PW, $21.5 \mathrm{~mm}$ ID, $15 \mathrm{~cm}$ length, $13 \mu \mathrm{m}$ particle size), initially pumping buffer C $\left(\mathrm{Na}_{2} \mathrm{HPO}_{4} 50 \mathrm{mM}\right.$, DTPA $1 \mathrm{mM}$, ammonium sulfate $1 \mathrm{M}, \mathrm{pH}$ 7.9) at $3 \mathrm{~mL} / \mathrm{min}$. Proteins were eluted by a gradient of buffer A developed at $2.3 \% / \mathrm{min}$.

The expected mass of the purified proteins was confirmed by HPLC- time of flight mass spectroscopy [1]. They were 16,706.9 Da for wild type calmodulin (99\% purity) with a calculated mass of 16,706.4 Da and 16,703.8 Da for M77Q calmodulin (70\% purity) with a calculated mass of 16,703.4 Da. The amount of both calmodulins was measured by the Bradford method [18] using Bio-Rad protein assay reagent and bovine serum albumin as a standard. The yield was $30 \mathrm{mg}$ of wild-type calmodulin and $7.5 \mathrm{mg}$ of the M77Q mutant.

To quantitate tissue calmodulin, $50 \mathrm{mg}$ of heart or muscle were minced and homogenized in $500 \mu \mathrm{L}$ RIPA buffer (Sigma R0278) with $1 \mathrm{mM}$ phenylmethanesulfonyl chloride and $1 \times$ Millipore Protease Inhibitor Mixture. Brain tissues were minced and then homogenized with a pestle. Muscle and heart tissues were homogenized using a Polytron homogenizer for $20 \mathrm{~s}$. Samples containing $10 \mu \mathrm{g}$ protein were reduced in SDS-PAGE buffer (Life Technologies LC2676, Carlsbad, CA, USA) containing $0.5 \%$ mercaptoethanol by heating at $95^{\circ}$ for $5 \mathrm{~min}$. Gel electrophoresis was performed on $10-20 \%$ Tris/glycine gels (15-well, $1.5 \mathrm{~mm}$; Invitrogen, XP10205BOX). A constant output power of $180 \mathrm{~V}$ was applied at room temperature for $90 \mathrm{~min}$. The proteins were then transferred to a nitrocellulose membrane (Biorad, 704158, Hercules, CA, USA). The membrane was incubated with a 1:1000 dilution of anti-calmodulin antibody (Abcam, catalog ab455689, Cambridge, MA, USA) overnight at $4^{\circ}$ and then with a 1:5000 dilution of the secondary antibody (Alexa Fluor 680 goat anti-rabbit IgG (Invitrogen A21109, Carlsbad, CA, USA) for $1 \mathrm{~h}$ at room temperature. The membrane was washed four times with 0.1\% Tween-20 (Sigma P5927) in phosphate-buffered saline (KD Medical RGF-3210). The calmodulin content was quantified by scanning with an Odyssey infrared scanner and associated Image Studio version 3 software (Li-Cor Biosciences, Lincoln, NE, USA). Calmodulin recombinant protein was used as the standard, loading from 0 to $10 \mathrm{ng}$ per lane. 
CaMKII $\alpha$ was assayed at $37^{\circ}$ with an incubation time of $10 \mathrm{~min}$. The $10 \mu \mathrm{L}$ assay solution for CaMKII $\alpha$ contained 50 mM HEPES (Teknova H0135, 1 M stock, pH 7.5), 10 mM magnesium acetate, $0.5 \mathrm{mM}$ calcium chloride, $0.4 \mathrm{mM}$ ATP, $50 \mu \mathrm{M}$ syntide-2 (PLARTLSVAGLPGKK; AnaSpec AS-22552), $1 \mathrm{mg} / \mathrm{mL}$ bovine serum albumin and calmodulin ranging from $10^{-9}$ to $10^{-6} \mathrm{M}$. The assay tubes were pre-incubated for $2 \mathrm{~min}$ and then the reaction was started by the addition of $20 \mathrm{ng}$ CaMKII $\alpha$ (Abcam ab60899). It was stopped by addition of $0.5 \mu \mathrm{L}$ of $20 \%$ trifluoroacetic acid. Phosphorylated syntide- 2 was separated from unmodified syntide- 2 by HPLC on a Zorbax $300 \AA$ StableBond C18 MicroBore column $(1.0 \times 50 \mathrm{~mm}, 3.5 \mu \mathrm{m}$ particle size, Agilent 865630-902) with an Agilent 1200 series high pressure liquid chromatography system equipped with an autosampler set to $4^{\circ}$ and a column compartment set to $30^{\circ}$. The initial solvent was water $/ 0.05 \%$ trifluoracetic acid and peptides were eluted by a gradient of acetonitrile $/ 0.05 \%$ trifluoroacetic acid with a flow rate of $20 \mu \mathrm{L} / \mathrm{min}$. Acetonitrile was ramped to $10 \%$ over $2 \mathrm{~min}$, then to $22 \%$ over the next $24 \mathrm{~min}$ and the column was washed by ramping to $95 \%$ in $4 \mathrm{~min}$. With this program, phosphorylated syntide- 2 eluted at $23.7 \mathrm{~min}$ and unphosphorylated syntide- 2 at $24.4 \mathrm{~min}$. The two forms of the peptide were quantitated from their areas in the chromatogram recorded at $210 \mathrm{~nm}$ with a $10 \mathrm{~nm}$ bandwidth. The calmodulin concentration curves were fit to an allosteric response and compared with Prism version 7 (GraphPad Software, La Jolla, CA, USA).

\subsection{Protein Array}

Wild-type and M77Q calmodulins were biotinylated with maleimide-PEG2-Biotin (Invitrogen, \# 21901) and then dialyzed $50 \mathrm{mM}$ HEPES, $150 \mathrm{mM} \mathrm{NaCl}$ and $1 \mathrm{mM}$ DTPA. The expected increase in mass of 525.6 Da was confirmed by HPLC-time of flight mass spectroscopy. The concentrations, $\sim 300 \mu \mathrm{M}$ were measured after which an aliquot was diluted to $0.10 \mu \mathrm{M}$ in buffer I (50 mM HEPES, $150 \mathrm{mM}$ $\mathrm{NaCl}, 5 \%$ glycerol, $0.05 \%$ TritonX-100, $1 \%$ bovine serum albumin, $5 \mathrm{mM} \mathrm{MgCl} 2,0.5 \mathrm{mM}$ dithiothreitol (DTT) and $2 \mathrm{mM} \mathrm{CaCl} 2$ ). The solution was incubated with $0.2 \mu \mathrm{g} / \mathrm{mL}$ streptavidin-conjugated Alexa 647 (Invitrogen S32357) in the dark at room temperature for $1 \mathrm{~h}$. Protein arrays (ProtoArray ${ }^{\circledR}$ Human Protein Microarray v. 5.0, Invitrogen) were incubated with blocking buffer (50 mM HEPES, $150 \mathrm{mM}$ $\mathrm{NaCl}, 0.1 \%$ Tween-20 and $1 \%$ bovine serum albumin (BSA)) for $1 \mathrm{~h}$ at $4^{\circ}$ and then incubated with the biotin-streptavidin complex for $2 \mathrm{~h}$ at $4^{\circ}$. Arrays were then washed 3 times with washing buffer II (50 mM HEPES, $150 \mathrm{mM} \mathrm{NaCl}, 0.1 \%$ Tween-20, $\%$ BSA, $5 \mathrm{mM} \mathrm{MgCl}_{2}$ and $0.5 \mathrm{mM}$ dithiothreitol [DTT]). Arrays were scanned with a GenePix 4200AL (Molecular Devices, San Jose, CA, USA) and analyzed with Invitrogen's ProtoArray Prospector software (Thermo Fisher Scientific, Waltham, MA, USA).

\subsection{Generation of the Calmodulin M77Q Mouse}

All animals were treated humanely in accordance with the Guide for the Care and Use of Laboratory Animals [19]. The study was approved by the Animal Care and Use Committee of the National Heart, Lung and Blood Institute (Study H-120R4 latest approval on 7 November 2017). An 200 bp genomic DNA sequence of Calm1 surrounding Met77 was submitted into MIT's CRISPR design website [20]. Two sgRNAs were selected based on their off-target scores and proximity to the mutation site, one upstream (Cam1-Upstream: CCCAGAGTTCTTGACTATGA) and the other downstream (Calm1-Downstream: CAAACACTCGGAAGGCCTCG) of the Met77. The Calm1-Upstream sgRNA is expected to cut $14 \mathrm{bp}$ upstream of Met77, the targeted mutation site. The Cam1-Downstream sgRNA is expected to cut 34 bp downstream of Met77.

The sgRNA binding sequences were cloned into a plasmid vector containing a T7 promoter using OriGene's (Rockville, Maryland) sgRNA cloning service. These plasmids were then used as templates for generating sgRNAs using the MEGAshortscript T7 Kit (ThermoFisher). For each sgRNA, a corresponding oligonucleotide donor (Calm1-Upstream: ACTGTTTCTCTTCTCATTAAAGGCAATGGCACCATTGACTTCCCCGAGTTTCT GACTATGATGGCTAGAAAACAGAAAGACACAGATAGCGAAGAAGAGATCCGCGAGGCCTT 
CCGAGTG; and Cam1-Downstream: GGCACCATTGACTTCCCAGAGTTCTTGAC TATGATGGCTAGAAAACAGA AAGACACAGATAGCGAAGAAGAGATTCGGGAGGCCTTCCGAG TGTTTGACAAGGTAA TCTTGCACACTGGCCTT) was purchased from Integrated DNA Technologies (Skokie, Illinois), which contains not only the desired changes for mutating Met77 but also 2-3 silent mutations which do not result in any amino acid changes but can assist in preventing Cas9 from continuingly cutting the DNA after the donor is knocked in. Each sgRNA $(50 \mathrm{ng} / \mu \mathrm{L})$ and its corresponding donor oligonucleotides $(100 \mathrm{ng} / \mu \mathrm{L})$ were co-microinjected with Cas9 mRNA (100 ng/ $\mu \mathrm{L}$ from Trilink BioTechnologies, San Diego, CA, USA) into the cytoplasm of zygotes collected from C57BL/6N mice. Injected embryos were cultured in M16 medium in a $37^{\circ}$ incubator with $6 \% \mathrm{CO}_{2}$. When embryos reached the 2-cell stage of development, they were implanted into the oviducts of pseudopregnant surrogate mothers. Offspring born to the foster mothers were genotyped by PCR and DNA sequencing for identifying founders with the desired nucleotide changes. After expansion of the colony, genotyping was carried out by PCR. Briefly, genomic DNA was extracted from tail snips using the REDExtract-N-Amp ${ }^{\mathrm{TM}}$ Tissue PCR Kit (Sigma XNAT-100RXN) and amplified by PCR with these primers: (5'-TGCACCTGTAGGTGCTCTGGGCACCGCC-3', 5'-GACTGCCCCATCTTTGTTCTGTTTGG-3'). DNA sequencing was performed by Macrogen USA.

\subsection{Treadmill Test}

Exercise capacity was tested using a Columbus Instruments rodent treadmill (Model Eco-6M), set at a 10 degree incline. Total exercise time, distance, maximum speed and work were recorded at the time of exhaustion which was defined as the moment the mouse was unable to continue running without repeatedly falling back onto the shock grid at the backend of the treadmill belt. The testing protocol was as follows: $10 \mathrm{~min}$ at $10 \mathrm{~m} / \mathrm{min}$, then $12 \mathrm{~m} / \mathrm{min}$ for five minutes. At minute 15 the belt speed was increased to $15 \mathrm{~m} / \mathrm{min}$ for three minutes and then increased $1.8 \mathrm{~m} / \mathrm{min}$ every three minutes until the mouse became exhausted.

\subsection{Dobutamine Cardiac Stress Test}

Six-month old mice were lightly anesthetized with isoflurane and placed on a heated platform with ECG leads and a rectal temperature probe to perform echocardiography exams before and after administering constant rate dobutamine infusions. Heart images were acquired using the Vevo2100 ultrasound system (VisualSonics, Toronto, ON, Canada) with a $30 \mathrm{MHz}$ ultrasound probe (VisualSonics, MS-400 transducer). After the baseline-scan, the mice received constant rate infusions of dobutamine $(0.625 \mathrm{mg} / \mathrm{mL}$ in normal saline containing $5 \%$ dextrose $)$, via the tail vein using an infusion syringe pump (Harvard Apparatus, Holliston, MA, USA). The low dose infusion rate was $10 \mu \mathrm{g} / \mathrm{kg} / \mathrm{min}$. After the heart rate reached a steady state as determined by the ECG, the rate was increased to $40 \mu \mathrm{g} / \mathrm{kg} / \mathrm{min}$ and the scans repeated.

\subsection{Spatial Learning Assessment with the Morris Water Maze}

A square platform with each side measuring $10 \mathrm{~cm}$ was placed in the northwest quadrant of a 6 foot diameter pool and submerged $1 \mathrm{~cm}$ below the water line. Non-toxic white tempura paint was added to the water so that the platform was not visible to the mice. Visual clues were placed around the pool and the room during the testing. Mice were acclimated and screened for swimming ability the day before the test. Mice received six sets of four $60 \mathrm{~s}$ trials over three consecutive days. The latency time to locate the platform was averaged for each set of four trials. On the last day, a $90 \mathrm{~s}$ probe trial was conducted to assess spatial memory. The platform was removed and the time the mice spent in each of the four quadrants of the pool was recorded. The total crossings in the zone that matched the location of the removed platform were also measured. Testing was measured and scored with Anymaze (Stoelting) video tracking system. 


\subsection{Open Field Test}

Mice were removed from their home cage and individually placed into a $16^{\prime \prime} \times 16^{\prime \prime} \times 16^{\prime \prime}$ Perspex arena viewing chamber where they were allowed to explore for $30 \mathrm{~min}$. Movements were recorded and analyzed with the Anymaze video tracking system. After the test, the mice were returned to their home cage.

\subsection{Associative Learning Test}

On day 1 , mice were placed in a $17 \mathrm{~cm} \times 17 \mathrm{~cm} \times 25 \mathrm{~cm}$ animal enclosure inside a sound attenuating chamber (Ugo Basile, Gemonio, Italy). The animal enclosure has a grid floor, lights on, clear Plexiglass walls and the scent of vanilla to create a unique environmental context (context 1 ). Baseline freezing was scored during the first three min in context 1 with the AnyMaze system. During the second three min, animals were exposed to two pairings of fifteen second $4000 \mathrm{~Hz}$ tones followed immediately by two $0.85 \mathrm{~mA}$ foot shocks of $3 \mathrm{~s}$ duration, delivered through the grid floor.

Twenty four hours after completing context 1 , the contextual learning test was conducted. Mice were placed back into the enclosure for three minutes with no auditory or shock stimuli and their freezing was measured. One hour later, mice were placed into a novel chamber (context 2) that was located in a different area of the room. This chamber had a different enclosure geometry and striped walls, with the lights were off, background noise on, a floor that was solid with bedding and no olfactory cue was provided. The auditory tone from day 1 was played in the novel enclosure and freezing time in response to the cue was recorded.

\subsection{Body Composition}

The body composition of mice was analyzed noninvasively at 18 months of age with an EchoMRI ${ }^{\mathrm{TM}}-100 \mathrm{H}$ (EchoMRI LLC, Houston, TX, USA). The mouse was placed in a clear plastic tube which was plugged by a plunger with air holes. The plunger was fitted to the mouse and tightened just sufficiently to minimize movement. The tube was then inserted into the instrument to a premeasured depth and measurements were collected. The mouse was then returned to its home cage.

\section{Results}

\subsection{Protein Array}

Oxidation and reduction of Met77 in calmodulin could function as an on-off switch by modulating interaction of the calmodulin with one or more specific targets. We used a human protein array to detect interactions of wild-type or M77Q calmodulin. The arrays are printed on nitrocellulose and have the same dimensions as cDNA arrays used for transcriptomics. They are also scanned in the same instruments as cDNA arrays. The protein array we employed has 9483 human proteins, produced in baculovirus with glutathione-S-transferase (GST) tags [21]. We had earlier used these arrays to demonstrate a protein-protein interaction of methionine sulfoxide reductase A that had not been detected by a number of other techniques [22]. In this study, we interrogated the protein arrays with recombinant wild-type or M77Q calmodulin. Although a number of proteins on the array bound the test proteins, none displayed a difference between the wild-type and M77Q forms.

\subsection{Calm1 was Mutated in M77Q Mice}

Two independent sgRNAs and corresponding donor oligonucleotides were designed and separately microinjected into C57BL/6N zygotes. Ten live offspring were obtained from embryos injected with Calm1-Upstream sgRNA and oligos but none of them carried the desired amino acid changes. However, 10 out 16 mice injected with Calm1-Downstream sgRNA and oligos harbored the desired Met to Gln change. This is a surprisingly high efficiency for an oligonucleotide-mediated knockin, especially considering that the introduced nucleotide changes are 34 bp away from the 
predicted sgRNA cutting position, because it is generally believed that the efficiency of single strand donor-mediated knockins decreases dramatically if the distance between the mutation site and cutting site is greater than $15-20 \mathrm{bp}$. We anticipated that the upstream sgRNA is more efficient than the downstream one because it cuts closer to Met77 but the exact opposite was observed here. These observations indicate that there are other factors determining the efficiency of oligonucleotide-mediated knockin.

DNA analysis of 2 independent founders confirmed that they harbored the desired mutation. These founders were then bred with C57BL/6N wild type mice for expanding the lines, as well as for eliminating possible mosaicism and diluting out off-target effects, if any. Genomic sequencing confirmed that the Met77 codon was changed to Gln77 in both copies of the Calm1 gene. Measurement of calmodulin showed that there was no change in tissue content (Figure 2).

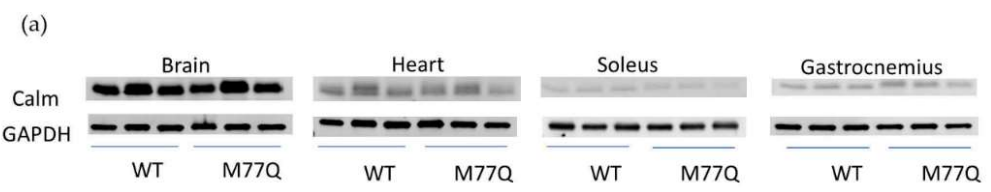

(b)

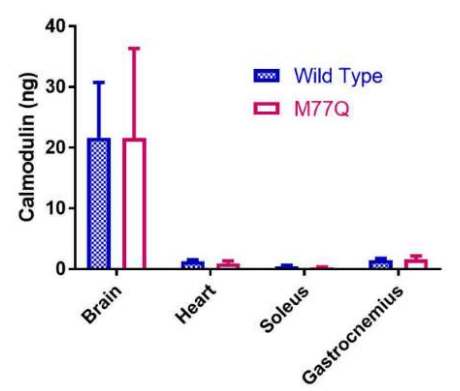

Figure 2. Measurement of total tissue calmodulin in 3 male mice. (a) Western blots; (b) Quantitation of blots. The abbreviations are Calm, calmodulin and WT, wild type.

\subsection{M77Q Mice are Growth Retarded When Younger and Become Fatter When Older}

M77Q mice were born at term, were viable and could reproduce. However, they were noticeably symmetrically smaller than their wild-type litter mates. We thus followed their growth from 2 to 4 months of age. Both males and females weighed $\sim 20 \%$ less than wild-type mice (Figure 3). However, their food intake per gram of body weight was the same as wild-type animals, so that they were constitutively smaller, indicating that the M77Q calmodulin affected growth programs (Figure 4). As the animals aged, we observed the M77Q mice became distinctly fatter than the wild type mice. This was confirmed by MRI determination of the lean and fat masses of the animals (Figure 5).
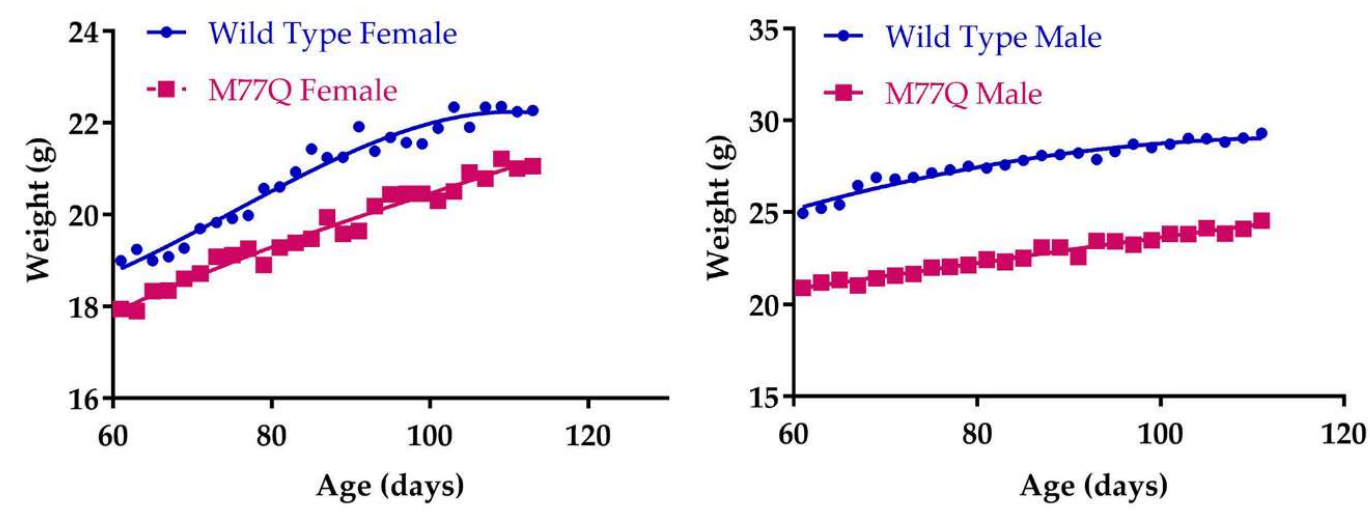

Figure 3. Growth curves. There were 7 mice in each group. 

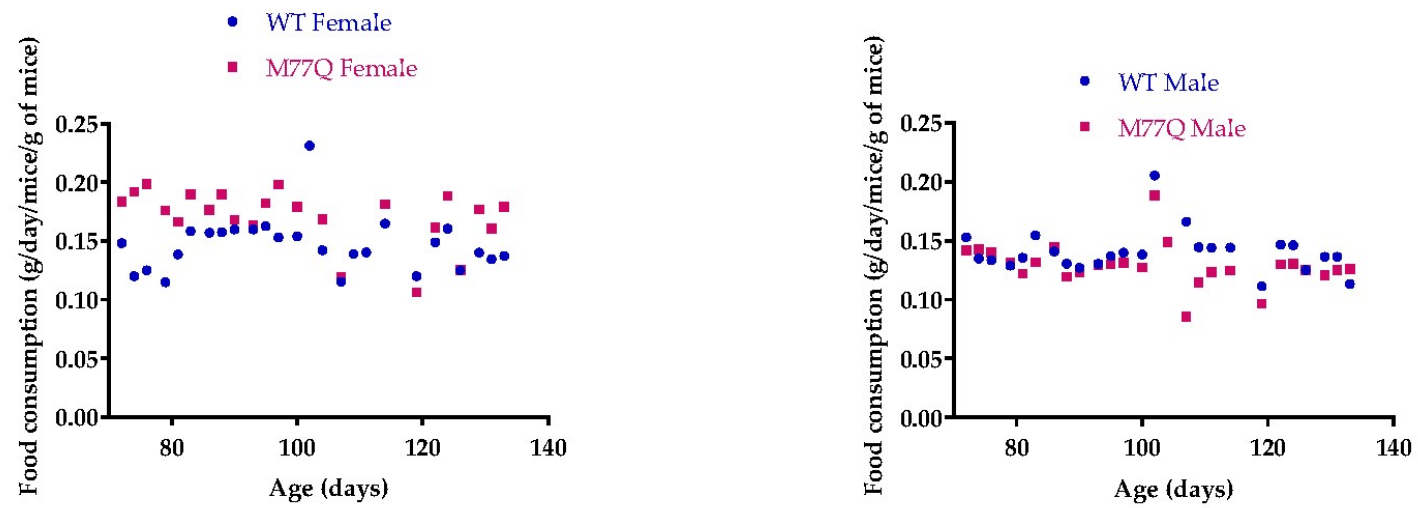

Figure 4. Food consumption. There were 4 mice in each group. The points are the average for the 4 mice. Regression lines were plotted separately for wild-type and M77Q mice but their slopes were not statistically significantly different.
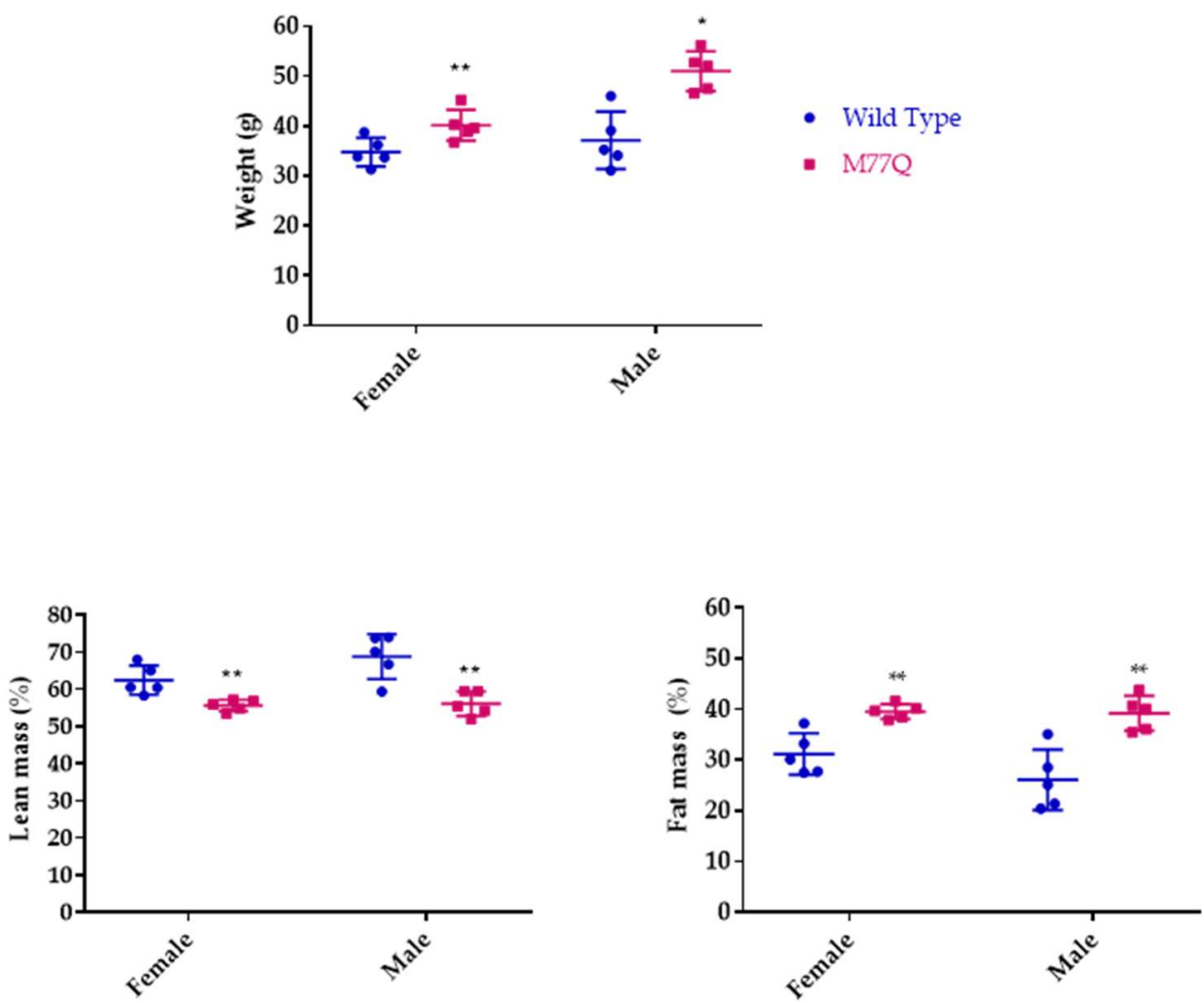

Figure 5. Body composition of mice at 18 months of age. There were 5 mice in each group. $\left({ }^{*} p<0.05\right.$, ** $p<0.01$ by $t$-test).

\subsection{Cardiac Stress Test and Endurance Running}

The relatively high level of expression of Calm1 in heart and skeletal muscle prompted assessment of cardiac function by a pharmacological stress, namely the intravenous infusion of dobutamine to increase cardiac rate and contractility. Except for the female heart rates, there was no difference between the wild-type and M77Q mice in the measured parameters, even at the highest dose of dobutamine (Table 1 and Figure 6). 
Table 1. Cardiac parameters from dobutamine stress tests at 6 months of age.

\begin{tabular}{|c|c|c|c|c|c|c|}
\hline & $\begin{array}{l}\text { Volume of LV } \\
\text { in Systole } \\
\left(\mathrm{mm}^{3}\right)\end{array}$ & $\begin{array}{l}\text { Volume of LV } \\
\text { in Diastole } \\
\left(\mathrm{mm}^{3}\right)\end{array}$ & $\begin{array}{c}\text { Ejection } \\
\text { Fraction (\%) }\end{array}$ & $\begin{array}{c}\text { Diam LV } \\
\text { Chamber in } \\
\text { Systole (mm) }\end{array}$ & $\begin{array}{c}\text { Diam LV } \\
\text { Chamber in } \\
\text { Diastole (mm) }\end{array}$ & $\begin{array}{c}\text { Heart Rate } \\
\text { (Beats Per } \\
\text { Minute) }\end{array}$ \\
\hline \multicolumn{7}{|c|}{ Baseline } \\
\hline WT female & $29.2 \pm 3.4$ & $72.3 \pm 7.4$ & $60 \pm 0.8$ & $2.8 \pm 0.1$ & $4 \pm 0.17$ & $491.9 \pm 45.8$ \\
\hline M77Q female & $30.5 \pm 2.2$ & $72.1 \pm 5.1$ & $58.9 \pm 1.5$ & $2.8 \pm 0.1$ & $4 \pm 0.12$ & $553.9 \pm 34.4$ \\
\hline WT male & $31 \pm 3.1$ & $77 \pm 4.7$ & $59.8 \pm 2.4$ & $2.9 \pm 0.1$ & $4.2 \pm 0.1$ & $502.3 \pm 33.8$ \\
\hline M77Q female & $30.78 \pm 2.5$ & $78.8 \pm 5.5$ & $60.9 \pm 1.7$ & $2.8 \pm 0.08$ & $4.2 \pm 0.12$ & $564.4 \pm 18.3$ \\
\hline \multicolumn{7}{|c|}{ Low Dose } \\
\hline WT female & $16 \pm 3.7$ & $59 \pm 9.1$ & $73 \pm 2.7$ & $2.2 \pm 0.2$ & $3.7 \pm 0.2$ & $558 \pm 40.4$ \\
\hline M77Q female & $18.1 \pm 5.3$ & $60.4 \pm 7.4$ & $70.7 \pm 5.3$ & $2.3 \pm 0.3$ & $3.8 \pm 0.2$ & $625.1 \pm 18.4$ \\
\hline WT male & $18.8 \pm 5.1$ & $65.3 \pm 7.6$ & $71.7 \pm 5$ & $2.3 \pm 0.2$ & $3.9 \pm 0.2$ & $623.5 \pm 37.5$ \\
\hline M77Q female & $19 \pm 8.6$ & $66.7 \pm 11.9$ & $73.1 \pm 9$ & $2.3 \pm 0.5$ & $3.9 \pm 0.3$ & $630.6 \pm 23.6$ \\
\hline \multicolumn{7}{|c|}{ High dose } \\
\hline WT female & $13.2 \pm 3.5$ & $55 \pm 11.5$ & $76.2 \pm 3.9$ & $2.0 \pm 0.2$ & $3.6 \pm 0.3$ & $587.3 \pm 47.4$ \\
\hline M77Q female & $13.2 \pm 2.9$ & $57.2 \pm 5.7$ & $77.2 \pm 4.0$ & $2.0 \pm 0.2$ & $3.7 \pm 0.2$ & $652.6 \pm 21.3$ \\
\hline WT male & $13.4 \pm 2.8$ & $59.4 \pm 5.8$ & $77.6 \pm 3.8$ & $2.0 \pm 0.2$ & $3.7 \pm 0.2$ & $667.3 \pm 49.2$ \\
\hline M77Q female & $15.6 \pm 7.4$ & $67.3 \pm 10.3$ & $77.8 \pm 8$ & $2.1 \pm 0.4$ & $3.9 \pm 0.3$ & $659.4 \pm 25.8$ \\
\hline
\end{tabular}
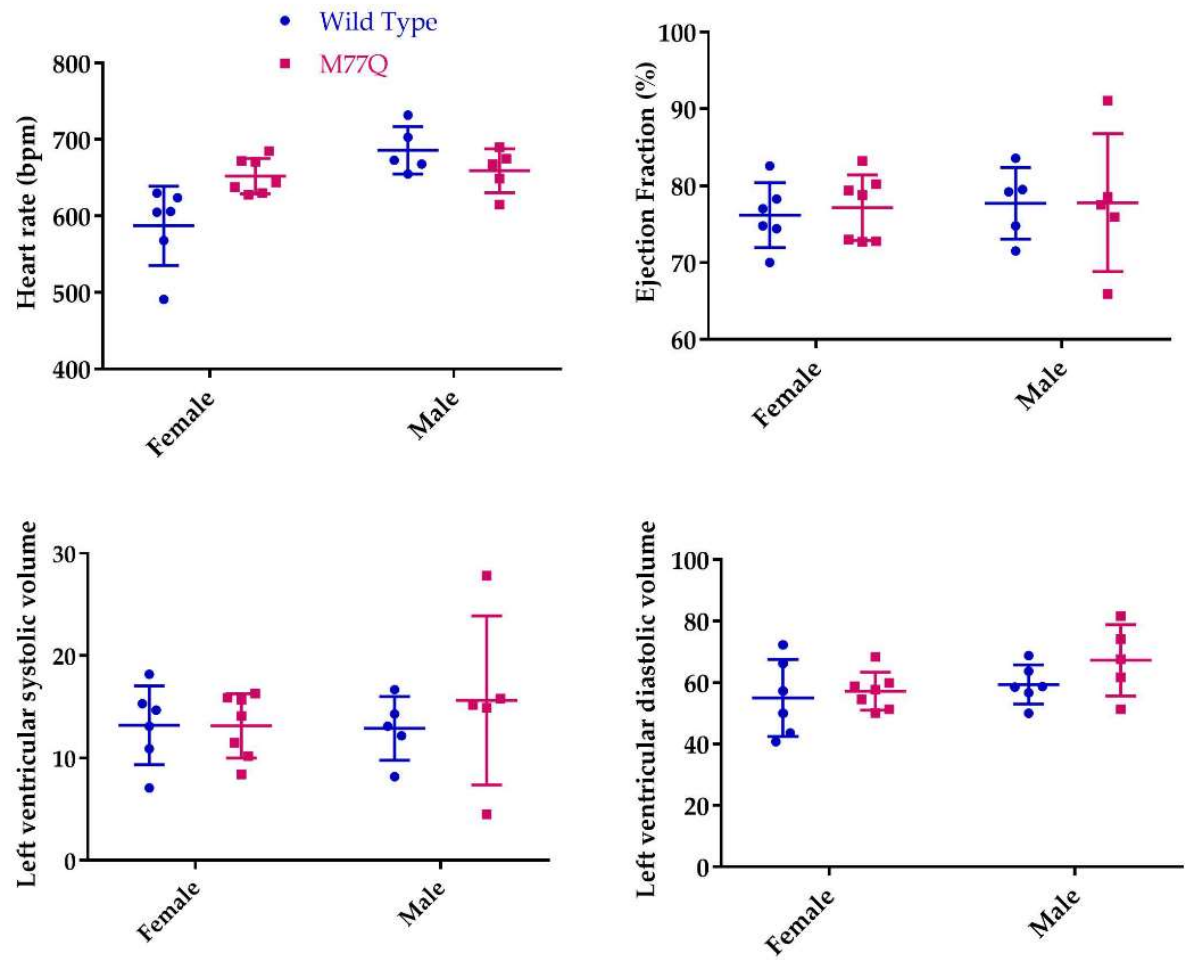

Figure 6. Cardiac parameters during high dose dobutamine stress test at 6 months of age. Except for the female heart rates $(p=0.05)$, none of the comparisons were statistically significantly different.

We observed that young M77Q mice were very active, running in their cages considerably more than their wild-type litter mate controls. This increased activity was evident by 2 months of age. We also noted that the increased activity decreased by 10 months of age. We therefore tested the mice at 6 and 10 months of age in which they run on a treadmill of increasing speed to the point of exhaustion [23]. When tested at 6 months of age, M77Q mice ran 20\% longer, with a 30\% increase in total distance run (Figure 7). Female M77Q mice ran slightly faster than wild-type, while the speed of running of the males did not reach a statistically significant difference. When the same mice were retested at 10 months of age, wild-type mice exhibited a modest but significant decrease in performance while the M77Q mice had a much greater decline (Figure 8). With these age-related changes, at 10 months of age, there was no difference in performance between wild-type and M77Q mice. 


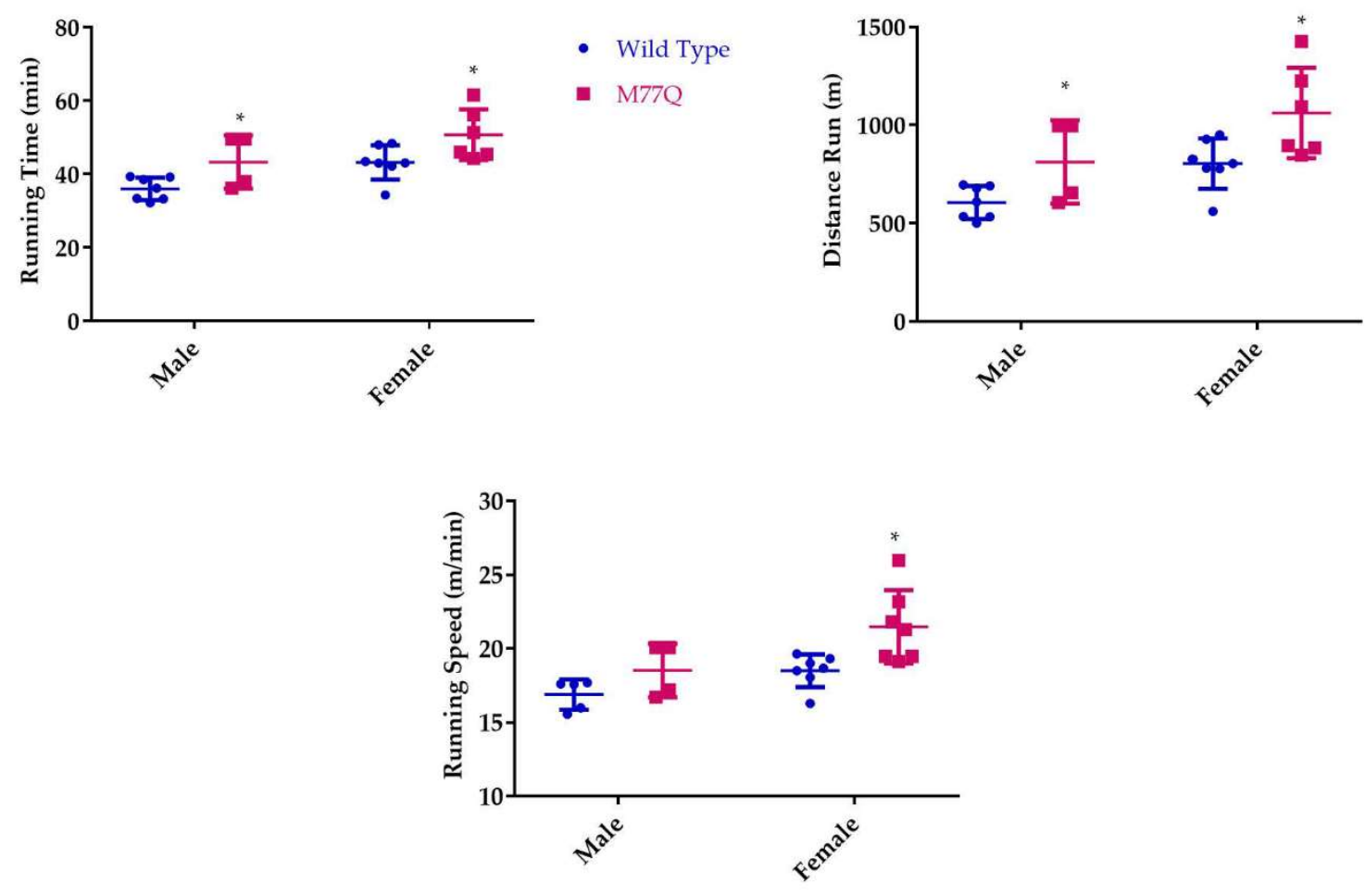

Figure 7. Treadmill test at 6 months of age. We tested 7 wild type and 4 M77Q males and 11 wild type and 8 M77Q females. The results from 1 M77Q were omitted as an outlier because they were greater than 3 standard deviations from the mean of the group. An asterisk marks the M77Q mice that differed significantly from the wild type $\left({ }^{*} p<0.05\right.$ by $t$-test).
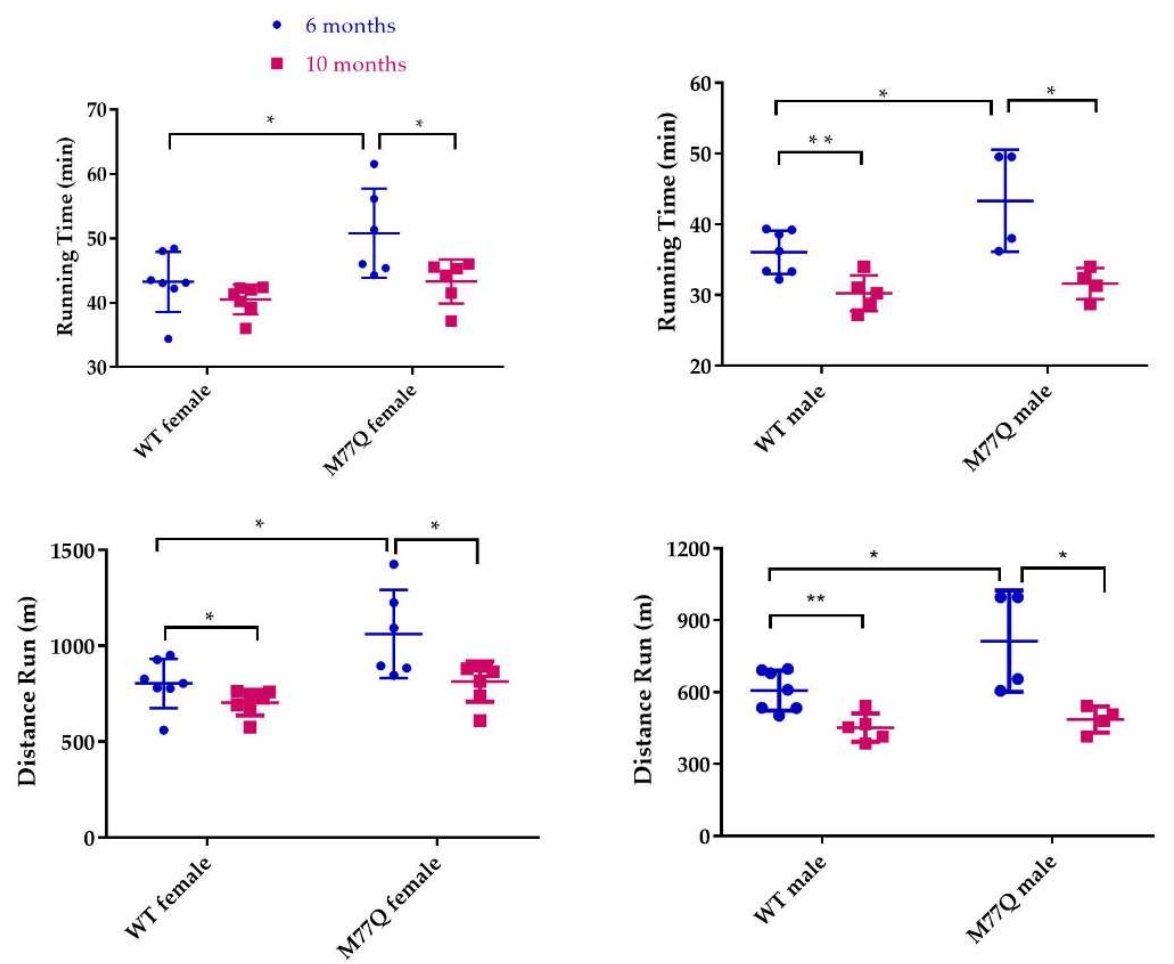

Figure 8. Comparison of treadmill test at 6 and 10 months of age. At 10 months, 5 wild type and 4 M77Q males were tested. Six wild type and 7 M77Q females were tested. ${ }^{*} p<0.05$, ${ }^{* *} p<0.01$, by $t$-test. 


\subsection{Neurobehavioral Phenotyping}

The very high level of expression of Calm1 in the brain led us to administer several tests to evaluate behavior, learning and memory, all at 6 months of age. The open field test of spontaneous activity requires normal motor skills and is suited for evaluation of anxiety level and response to a novel environment [24]. In this test, the mouse is placed in a square box for $30 \mathrm{~min}$ and movement is recorded by a camera and evaluated by computer. Wild-type mice move more around the periphery, avoiding the central region. Mice that spend more time in the center are considered to have reduced levels of fear of danger from predators. The M77Q mice readily explored the central area while wild-type controls tended to avoid it (Figure 9). The M77Q mice were mobile for a greater fraction of their time in the box and they traveled farther (Figure 10). These objective results are consistent with our subjective impression that the M77Q mice were much more active in their cages than the wild-type mice. The open field test was not repeated at 10 months of age.

We assessed associative learning with a classical Pavlovian conditioning test [25] in which associative learning is quantitated by the time that the mice freeze their movements. On the first day, they are placed in a box and a sound is delivered via a speaker. Thirty seconds later they receive a mild electrical footshock. The next day they are returned to the identical box to test their contextual memory. On the third day, they are placed in a very different box and the acoustic stimulus is again played in order to evaluate learning from the sound. As expected, freezing time increased with both the contextual and acoustic tests but there was no difference between the wild-type and M77Q mice indicating intact associative learning in the mutant (Figure 11).

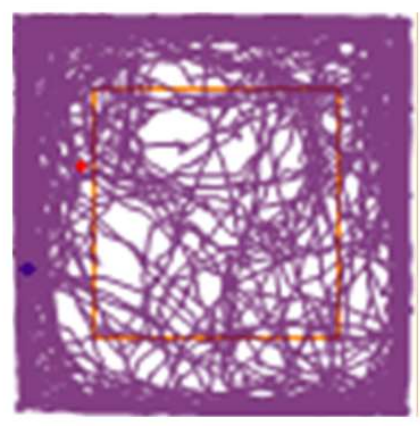

Wild type female

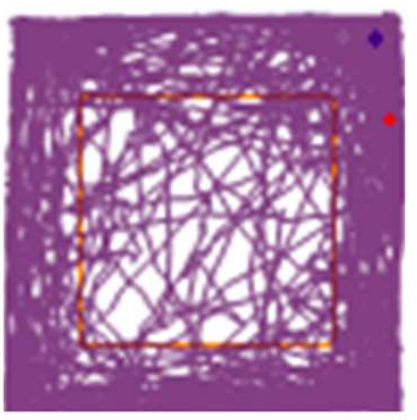

Wild type male

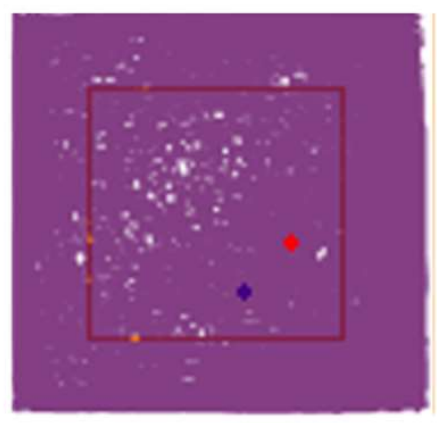

M77Q female

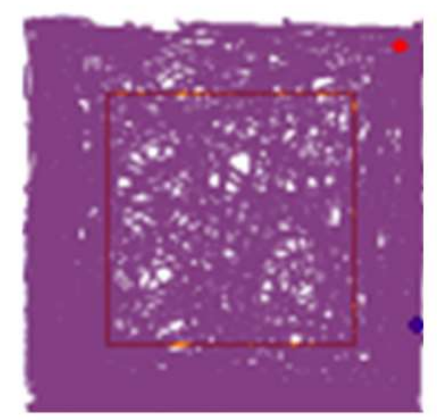

M77Q male

Figure 9. Track plots of mice during the open field test at 6 months of age. 

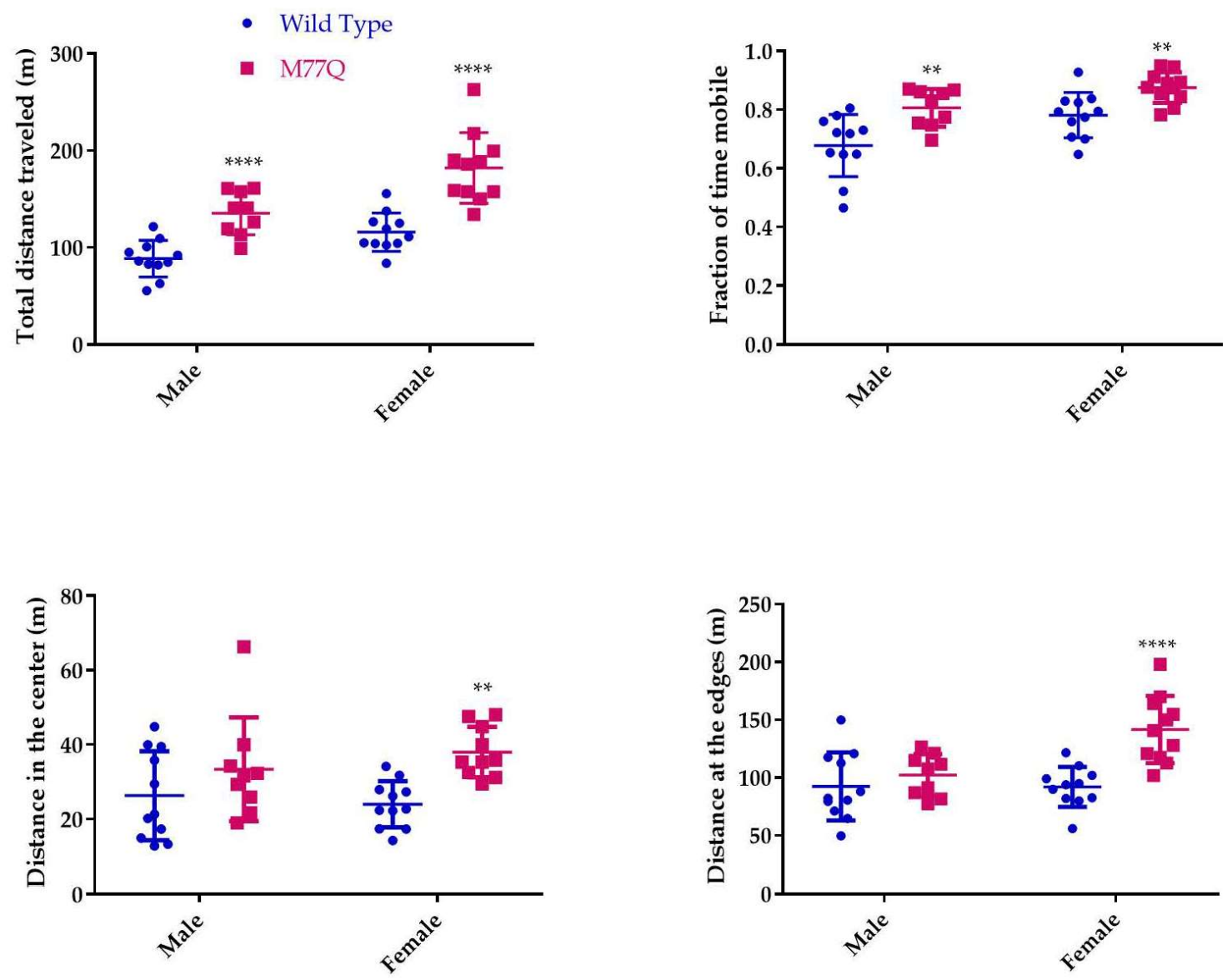

Figure 10. Quantitation of performance on the open field test. We tested 11 wild type and 9 M77Q males and 11 wild type and 10 M77Q females. ${ }^{* *} p<0.01,{ }^{* * * *} p<0.0001$ by $t$-test.
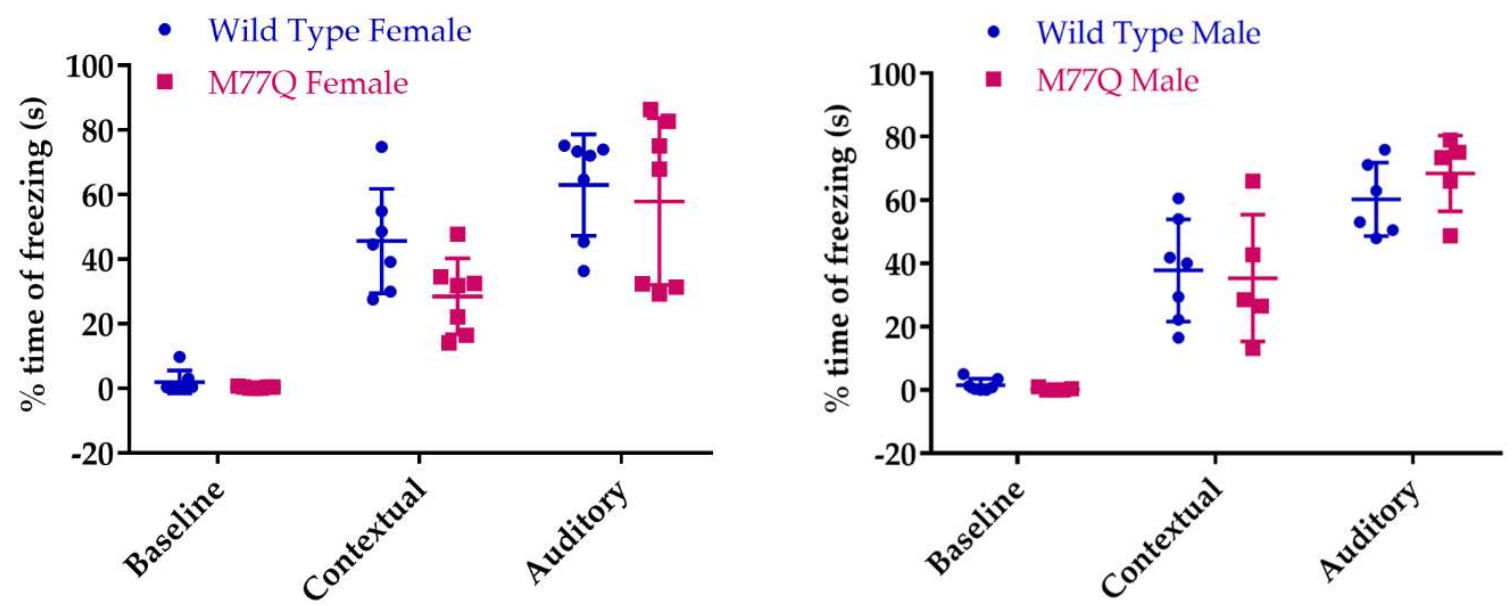

Figure 11. Fraction of time in which the mice freeze during the associative conditioning test. We tested 7 wild type and 5 M77Q males and 7 wild type and 7 M77Q females.

We also assessed learning with the Morris water maze in which visual cues guide a mouse to a hidden underwater platform so that they may stand rather than being forced to swim [26]. The test is repeated daily, during which the time for a normal mouse to reach the platform decreases as it learns to follow the visual cues. As in the associative learning test, we did not observe any difference between the wild type and M77Q mice (Figure 12). 

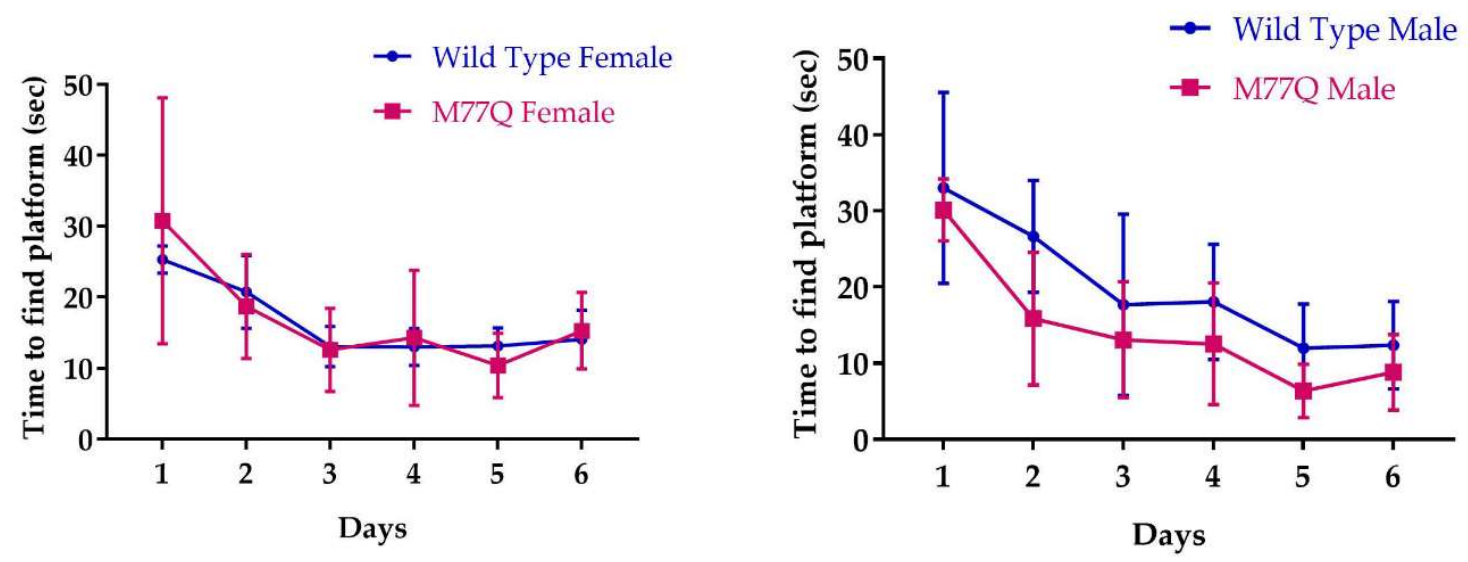

Figure 12. Learning performance on the Morris water maze. We tested 7 wild type and 5 M77Q males and 7 wild type and 7 M77Q females.

\subsection{Activation of Calcium/Calmodulin Dependent Protein Kinase II}

Mignogna and Viggiano compiled a database of mouse knockouts that displayed altered motor activity [27]. They identified 46 genes that caused increased activity when deleted, two of which are well known calmodulin dependent enzymes: cyclic phosphodiesterase 1 and (CaMKII $\alpha)$. We previously compared the activation of cyclic phosphodiesterase 1 by wild-type and Met77MetO calmodulins and found them to be identical. With regard to CaMKII $\alpha$, mice lacking this kinase are more active in the open field test and spend more time in the center than do control mice [28], as we observed for our mutant mice. From the crystal structure of calmodulin bound to CaMKII $\delta$, one can see that oxidation of Met77 to MetO could cause a clash with Met308 of CaMKII $\delta$ [29]. We therefore compared activation of CaMKII $\alpha$ by wild-type and MetO calmodulins (Figure 13). We found that MetO calmodulin is indeed less effective in activating CaMKII $\alpha$ than the wild type calmodulin $(p<0.0001$ by extra sum of squares $\mathrm{F}$ test).

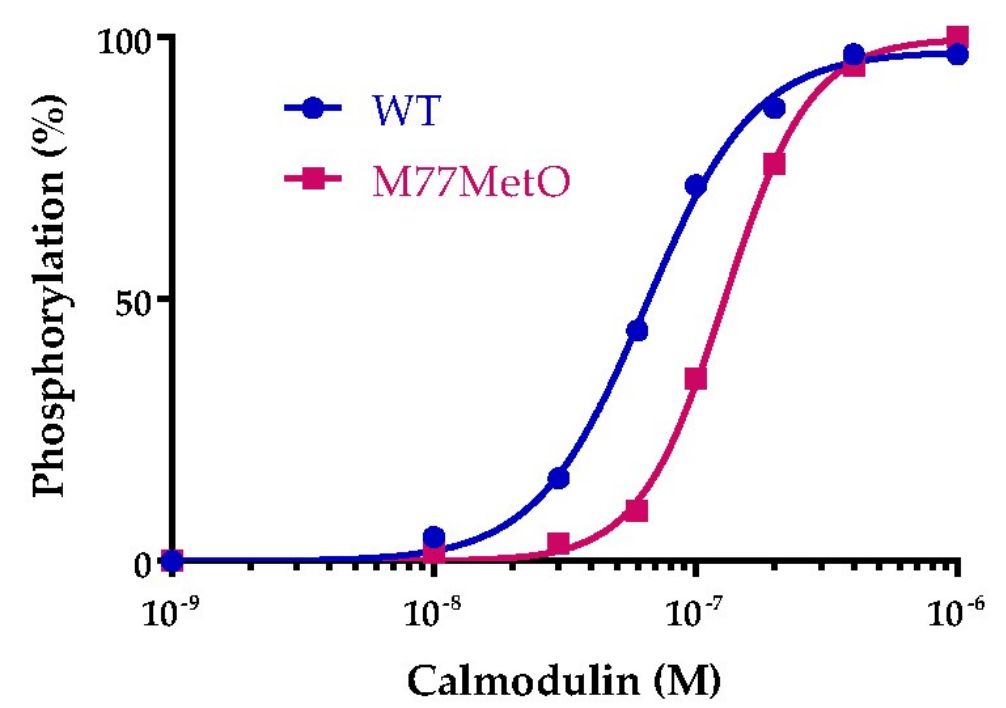

Figure 13. Activation of CaMKII $\alpha$ by wild type and M77MetO calmodulin. The experiment was performed in 3 separate experiments on different days and the values for each concentration of calmodulin were averaged to generate the plotted points. Curves were fit to an allosteric dose response by Prism.

Half maximal activation required $64 \mathrm{nM}$ wild type calmodulin while half maximal activation with M77MetO calmodulin required $129 \mathrm{nM}$. The concentration of calcium-bound calmodulin required to 
activate dependent proteins varies from $<10 \mathrm{nM}$ for high-affinity targets, $10-100 \mathrm{nM}$ for intermediate affinity targets and $>100 \mathrm{nM}$ for low affinity targets [30]. Thus, the shift from 64 to $129 \mathrm{nM}$ can have substantial effects on calmodulin dependent proteins.

\section{Discussion and Conclusions}

Calmodulin consists of two lobes, one formed by the amino terminal domain and one formed by the carboxy terminal domain [31]. These are joined by a connecting alpha helix, so that the structure resembles a dumbbell. Two calcium ions can be bound in each lobe and methionine residues in each lobe are important in the subsequent interaction of calmodulin with its targets. Met77 is situated very close to the end of the connecting alpha helix. While it is established that MSRA can mediate the reversible oxidation of calmodulin at Met77, to date there are no reports that implicate Met77 in target specificity. Thus, the aim of our study was to identify calmodulin-dependent proteins whose activity or function were modulated by covalent modification of Met77.

To this end, we first employed a human protein array with almost 10,000 proteins as a bioaffinity technique to detect potential candidates. No differences were observed in the binding of wild-type and M77Q calmodulin. Since the arrays were probed with a relatively high concentration of the calmodulins, the method would not detect differences in affinity of the two calmodulin forms. Nevertheless, the failure to identify candidates left unanswered the question of whether M77Q participated in regulatory functions in vivo.

We therefore generated a mutant mouse in which the M77Q calmodulin replaced wild-type calmodulin-1, giving a model of constitutive expression of calmodulin with MetO at residue 77. Learning and cardiac function was normal in the tests that we administered. Phenotypic characterization of the M77Q demonstrated substantive in vivo effects. Their growth, presumably prenatal as well as postnatal, was decreased so that mature M77Q mice weighed $20 \%$ less than wild-type littermates but with age they became obese.

The mutant mice were noticeably more active at a young age, a subjective evaluation that was confirmed by objective testing and they ran longer in the forced treadmill test. As noted above, the differences were no longer observed at 10 months of age, perhaps because of increased fat mass. The differences established by neurobehavioral testing resembled those described for knockout mice lacking CaMKII $\alpha$. In vitro assays with recombinant proteins established that M77MetO calmodulin was less effective than the wild type in activating recombinant CaMKII $\alpha$. Thus, characterization of the phenotype of a mouse expressing a constitutively active mimic of calmodulin oxidized at Met77 led to the identification of the first calmodulin target that is differentially affected by the oxidation state of Met77. The in vivo significance of the difference must be evaluated in future experiments, for example, by determining the fractional phosphorylation of CAMKII $\alpha$ substrates. Additional studies must also assess which, if any, of the phenotypic changes in the M77Q mouse are a consequence of this differential effect.

Author Contributions: Conceptualization, R.L.L.; Methodology, M.M., D.A.S., C.L., G.K., R.L.L.; Formal Analysis, M.M., D.A.S., R.L.L.; Writing-Original Draft Preparation, M.M.; Writing-Review \& Editing, M.M., D.A.S., C.L., G.K., R.L.L.

Funding: This research was supported by the Intramural Research Program of the National Heart, Lung and Blood Institute (ZIA HL000225).

Acknowledgments: The National Heart, Lung, and Blood Institute's Transgenic Core generated the M77Q mutant mice. Phenotypic evaluation was performed in the Murine Phenotyping Core of the National Heart, Lung, and Blood Institute and we thank Morteza Peiravi for his contributions to the phenotyping.

Conflicts of Interest: The authors declare no conflict of interest. The funders had no role in the design of the study; in the collection, analyses, or interpretation of data; in the writing of the manuscript and in the decision to publish the results.

Availability of Calmodulin M77Q Mice: Breeders will be made available to all qualified investigators. Collaboration with the authors is not required. 


\section{References}

1. Levine, R.L.; Mosoni, L.; Berlett, B.S.; Stadtman, E.R. Methionine residues as endogenous antioxidants in proteins. Proc. Natl. Acad. Sci. USA 1996, 93, 15036-15040. [CrossRef] [PubMed]

2. Bender, A.; Hajieva, P.; Moosmann, B. Adaptive antioxidant methionine accumulation in respiratory chain complexes explains the use of a deviant genetic code in mitochondria. Proc. Natl. Acad. Sci. USA 2008, 105, 16496-16501. [CrossRef] [PubMed]

3. Valley, C.C.; Cembran, A.; Perlmutter, J.D.; Lewis, A.K.; Labello, N.P.; Gao, J.; Sachs, J.N. The methionine-aromatic motif plays a unique role in stabilizing protein structure. J. Biol. Chem. 2012, 287, 34979-34991. [CrossRef] [PubMed]

4. Lee, B.C.; Peterfi, Z.; Hoffmann, F.W.; Moore, R.E.; Kaya, A.; Avanesov, A.; Tarrago, L.; Zhou, Y.; Weerapana, E.; Fomenko, D.E.; et al. MsrB1 and MICALs regulate actin assembly and macrophage function via reversible stereoselective methionine oxidation. Mol. Cell 2013, 51, 397-404. [CrossRef] [PubMed]

5. Hung, R.J.; Spaeth, C.S.; Yesilyurt, H.G.; Terman, J.R. SelR reverses Mical-mediated oxidation of actin to regulate F-actin dynamics. Nat. Cell Biol. 2013, 15, 1445-1454. [CrossRef] [PubMed]

6. Hung, R.-J.; Pak, C.W.; Terman, J.R. Direct redox regulation of F-actin assembly and disassembly by Mical. Science 2011, 334, 1710-1713. [CrossRef] [PubMed]

7. Netzer, N.; Goodenbour, J.M.; David, A.; Dittmar, K.A.; Jones, R.B.; Schneider, J.R.; Boone, D.; Eves, E.M.; Rosner, M.R.; Gibbs, J.S.; et al. Innate immune and chemically triggered oxidative stress modifies translational fidelity. Nature 2009, 462, 522-526. [CrossRef] [PubMed]

8. Lee, J.Y.; Kim, D.G.; Kim, B.G.; Yang, W.S.; Hong, J.; Kang, T.; Oh, Y.S.; Kim, K.R.; Han, B.W.; Hwang, B.J.; et al. Promiscuous methionyl-tRNA synthetase mediates adaptive mistranslation to protect cells against oxidative stress. J. Cell Sci. 2014, 127, 4234-4245. [CrossRef] [PubMed]

9. Lim, J.C.; You, Z.; Kim, G.; Levine, R.L. Methionine sulfoxide reductase A is a stereospecific methionine oxidase. Proc. Natl. Acad. Sci. USA 2011, 108, 10472-10477. [CrossRef] [PubMed]

10. Lim, J.C.; Kim, G.; Levine, R.L. Stereospecific oxidation of calmodulin by methionine sulfoxide reductase A. Free Radic. Biol. Med. 2013, 61, 257-264. [CrossRef] [PubMed]

11. Yap, K.; Kim, J.; Truong, K.; Sherman, M.; Yuan, T.; Ikura, M. Calmodulin target database. J. Struct. Funct. Genomics 2000, 1, 8-14. [CrossRef] [PubMed]

12. Jiang, G.; Wu, F.; Li, Z.; Li, T.; Gupta, V.K.; Duan, X.; Jiang, Y. Sulfoxidation regulation of Musa acuminata calmodulin (MaCaM) Influences the functions of MaCaM-binding proteins. Plant Cell Physiol. 2018, 59, 1214-1224. [CrossRef] [PubMed]

13. Friedberg, F.; Rhoads, A.R. Evolutionary aspects of calmodulin. IUBMB Life 2001, 51, 215-221. [PubMed]

14. Chin, D.; Means, A.R. Methionine to glutamine substitutions in the C-terminal domain of calmodulin impair the activation of three protein kinases. J. Biol. Chem. 1996, 271, 30465-30471. [CrossRef] [PubMed]

15. Drazic, A.; Miura, H.; Peschek, J.; Le, Y.; Bach, N.C.; Kriehuber, T.; Winter, J. Methionine oxidation activates a transcription factor in response to oxidative stress. Proc. Natl. Acad. Sci. USA 2013, 110, 9493-9498. [CrossRef] [PubMed]

16. Veredas, F.J.; Cantón, F.R.; Aledo, J.C. Methionine residues around phosphorylation sites are preferentially oxidized in vivo under stress conditions. Sci. Rep. 2017, 7, 40403. [CrossRef] [PubMed]

17. Bigelow, D.J.; Squier, T.C. Thioredoxin-dependent redox regulation of cellular signaling and stress response through reversible oxidation of methionines. Mol Biosyst 2011, 7, 2101-2109. [CrossRef] [PubMed]

18. Bradford, M.M. A rapid and sensitive method for the quantitation of microgram quantities of protein utilizing the principle of protein-dye binding. Anal. Biochem. 1976, 72, 248-254. [CrossRef]

19. National Research Council. Guide for the Care and Use of Laboratory Animals; National Academies Press: Washington, DC, USA, 2011.

20. CRISPR Design. Available online: http:/ / crispr.mit.edu/ (accessed on 11 October 2018).

21. Thermo Fisher Scientific. ProtoArray®Applications Guide. Available online: http://tools.thermofisher.com/ content/sfs/manuals/protoarray_applicationsguide_man.pdf (accessed on 11 October 2018).

22. Lim, J.M.; Lim, J.C.; Kim, G.; Levine, R.L. Myristoylated methionine sulfoxide reductase A is a late endosomal protein. J. Biol. Chem. 2018, 293, 7355-7366. [CrossRef] [PubMed] 
23. Kregel, K.C.; Allen, D.L.; Booth, F.W.; Fleshner, M.R.; Henriksen, E.J.; Musch, T.; O'Leary, D.; Parks, C.; Poole, D.; Ra'anan, A.; et al. Resource Book for the Design of Animal Exercise Protocols. Available online: http://www.the-aps.org/mm/SciencePolicy/AnimalResearch/Publications/Animal-ExerciseProtocols/book14824.pdf (accessed on 7 February 2006).

24. Pritchett, K.; Mulder, G.B. Open-field assessment of spontaneous activity. J. Amer. Assoc. Lab. Animal Sci. 2003, 42, 57-58.

25. Kim, J.J.; Jung, M.W. Neural circuits and mechanisms involved in Pavlovian fear conditioning: A critical review. Neurosci. Biobehav. Rev. 2006, 30, 188-202. [CrossRef] [PubMed]

26. Mulder, G.B.; Pritchett, K. The Morris water maze. J. Amer. Assoc. Lab. Animal Sci. 2003, 42, 49-50.

27. Mignogna, P.; Viggiano, D. Brain distribution of genes related to changes in locomotor activity. Physiol. Behav. 2010, 99, 618-626. [CrossRef] [PubMed]

28. Chen, C.; Rainnie, D.G.; Greene, R.W.; Tonegawa, S. Abnormal fear response and aggressive behavior in mutant mice deficient for alpha-calcium-calmodulin kinase II. Science 1994, 266, 291-294. [CrossRef] [PubMed]

29. Rellos, P.; Pike, A.C.W.; Niesen, F.H.; Salah, E.; Lee, W.H.; von Delft, F.; Knapp, S. Structure of the CaMKII $/$ Calmodulin complex reveals the molecular mechanism of CaMKII kinase activation. PLOS Biol. 2010, 8, e1000426. [CrossRef] [PubMed]

30. Persechini, A.; Cronk, B. The relationship between the free concentrations of $\mathrm{Ca}^{2+}$ and $\mathrm{Ca}^{2+}$-calmodulin in intact cells. J. Biol. Chem. 1999, 274, 6827-6830.

31. Finn, B.E.; Forsén, S. The evolving model of calmodulin structure, function and activation. Structure 1995, 3 , 7-11. [CrossRef]

(C) 2018 by the authors. Licensee MDPI, Basel, Switzerland. This article is an open access article distributed under the terms and conditions of the Creative Commons Attribution (CC BY) license (http:/ / creativecommons.org/licenses/by/4.0/). 